\title{
The Provision of Remedies for Enforcement of Fundamental Rights in Malaysia: Challenges and Prospects
}

\author{
Gan Chee Keong ${ }^{1}$ \\ Ahmad Azam Mohd Shariff ${ }^{2}$ \\ Ramalinggam Rajamanickam ${ }^{3}$ \\ Nazura Abdul Manap 4 \\ ${ }_{1}$ Postgraduate Student, Faculty of Law, Universiti Kebangsaan Malaysia; mercury_360@hotmail.com \\ ${ }^{2}$ Associate Professor, Faculty of Law, Universiti Kebangsaan Malaysia; aazam@ukm.edu.my \\ ${ }^{3}$ Lecturer, Faculty of Law, Universiti Kebangsaan Malaysia; rama@ukm.edu.my \\ ${ }^{4}$ Associate Professor, Faculty of Law, Universiti Kebangsaan Malaysia; nazura@ukm.edu.my
}

\section{Doi:10.5901/mjss.2016.v7n2p30}

\section{Abstract}

This article aims at analysing the provision of remedies for enforcement of fundamental rights in Malaysia in respect of the challenges faced and the hope that desired. It is known that where there are rights, there will be a remedy. Rights without remedies are meaningless. So, the relationship between rights and remedies are interrelated of one and another. In Malaysia, when the Constitution drafted by the Reid Commission, the provision of fundamental rights and the provision of remedies for enforcement of fundamental rights has been proposed in the draft Constitution. However, when the proposed draft Constitution was revised by the Working Party, the provision of remedies for enforcement of fundamental rights have been taken away from the draft Constitution on the footing that the said remedies will be best provided under an ordinary law. Hence, in the present Federal Constitution of Malaysia the fundamental rights are enshrined under the Federal Constitution, but the provision of remedies for enforcement of fundamental rights is provided under an ordinary legislation. Under an ordinary law, the provision of the remedies for enforcement of fundamental rights had faced several challenges in terms of protection of the rights, interpretation and judicial attitudes. A possibility to resolve this dilemma could be re-inserting the provision of the remedies for enforcement of fundamental rights in the Constitution as proposed by the Reid Commission in 1957.

Keywords: remedies; rights; enforcement of fundamental rights; interpretation; judicial attitude

\section{Introduction}

The provision of remedies for enforcement of fundamental rights plays an important role in preserving and defending the fundamental rights in the Constitution. Hence, the said provision is better catered for under the Constitution than under an ordinary legislation to ensure strength in upholding fundamental rights. Few researches have been carried out to examine the salient features of the said provision, but to date, study on the challenges faced by the provision of remedies for enforcement of fundamental rights that provided under an ordinary law still does not conducted. Therefore, the aim of this paper is to probe the challenges of the provision of remedies for enforcement of fundamental rights under ordinary law and the grandness of the provisions contained in the Constitution. This work should be conducted out in order to identify the problems encountered and recommend a solution to these troubles.

\section{The Provision of Remedies for Enforcement of Fundamental Rights in Malaysia}

In Malaysia, when the Constitution drafted by the Reid Commission, the provision of fundamental rights and the provision of remedies for enforcement of fundamental rights have been proposed in the draft Constitution. Nonetheless, when the proposed draft Constitution was revised by the Working Party, the provision of remedies for enforcement of fundamental rights have been removed from the draft Constitution on the ground that the said remedies will be best provided under an ordinary law. Hence, the provision of remedies for enforcement of fundamental rights are not enshrined in the Federal Constitution, but is provided under an ordinary Act of Parliament, namely the Courts of Judicature Act 1964 (V. Anantaraman, 2006). In the Courts of Judicature Act 1964, in particular Section 25 refers to 'additional powers' of the 
High Court, which is set out in the Schedule in the Courts of Judicature Act. The related paragraph in the Schedule is Paragraph 1 which enumerates the powers as follow:

"Power to issue to any person or authority directions, orders or writs, including writs of the nature of habeas corpus, mandamus, prohibition, quo warranto and certiorari, or any others, for the enforcement of the rights conferred by Part II of the Constitution, or any of them, or for any purpose."

In other words, the power of the courts to issue remedies for the enforcement of fundamental rights is conferred under Paragraph 1 of the Schedule in the Courts of Judicature Act. It is to be noted that the scheduled power in Paragraph 1 is in pari materia with Article 226 of the Indian Constitution (Choo Chin Thye, 2002). The only difference is that the powers under Article 226 are conferred by the Constitution, but in Malaysia, the source of such power is an ordinary law. The Indian Courts have given a wide construction to Article 226 of which the provision give powers to the High Courts to issue any order, including any order in the nature of the common law prerogative writs, not only for the purpose of enforcement of fundamental rights guaranteed by the constitution, but for 'any other purpose'. Although there are similarity of language between Article 226 of the Indian Constitution and Paragraph 1 of the Schedule in the Courts of Judicature Act 1964, but the approach taken by the Malaysian Courts in terms of giving remedies in public law is quite different, reason being the remedies for enforcement of fundamental rights is provided under the ordinary legislation.

\section{Challenges under Ordinary Legislation}

In Malaysia, the provision of remedies for enforcement of fundamental rights under the ordinary law has led to a number of challenges in terms of protection of rights, interpretation and judicial attitudes.

\subsection{Protection of Fundamental Rights}

As an ordinary law is passed by Parliament, then the law is guaranteed by the Parliament. Fundamental rights under the Constitution are meaningless unless there is a provision to preserve and protect the rights by ensuring those rights can be enforced. Thus, when the provision of the remedies for enforcement of fundamental rights under Paragraph 1 is provided under an ordinary law, it means that the provisions which maintaining and preserving the fundamental rights under the Constitution is guaranteed by the Parliament. It is not safe to have the provision guaranteed by the Parliament because the existence of the provision itself is dependent on the desire of a government or the ruling political party.

This is because under the Westminster system, Parliament is dominated by the executive body as it is the qualification to form the government. The membership of the executive may overlap with the Parliament as members of the Cabinet are often members of the Legislative (Oliver Wijetillake, 1982). Therefore, the government is part of the Parliament and the prime minister and his cabinet must belong to Parliament. If the government of the day intends to curtail the powers under Paragraph 1, they can do so with impunity because any motion brought by a ministry in the Parliament will normally have the support of the members of Parliament, especially from the same political party on the basis of party solidarity and party discipline. Due to this political atmosphere, members of Parliament are obliged to follow the wishes of the party rather to vote according to their own conscience. Party leaders appear to have complete control over their own rank and file. This is because party members are aware that the plums of office go to those who acquiesce with the decisions of their leaders and who are not troublemakers. More so, in Malaysia the ruling party has always enjoyed a position of strength in Parliament and therefore, has little difficulty in getting the necessary votes to support their proposals (Ahmad Masum, 2012).

On top of that, under an ordinary law, the provision of law can be easily removed by Parliament because any amendment to an ordinary law requires a simple majority as opposed to a two-third majority required for the Constitution. Since independence, the Malaysia government has always been having more than a two-third majority in Parliament. Hence, if the government wishes to amend or repeal the provision of Paragraph 1 of the Schedule to the Courts of Judicature Act 1964, it would be able to do so because the government has control over the Parliament and the amendment of an ordinary law only requires a simple majority vote. Finally, the Parliament is composed of different members of political party, either from the party that forms the government or the opposition parties, each of them will be guided more by political interests than by a desire for pure justice. With the political interests in mind then it is not safe for the provisions which protect and maintain the fundamental rights to be guaranteed by the Parliament. Based on the above reasons, the provision of remedies for enforcement of fundamental rights provided under an ordinary law is not safeguarded and it affected the protection of fundamental rights under the Federal Constitution. 


\subsection{Interpretation}

In terms of interpretation, interpreting the provisions of a statute, one of the cardinal rules is to adhere as closely as possible to the literal meaning of the words. If the meaning of the words in the statute is clear, certain or unambiguous, the courts will interpret them literally, by giving them their plain and natural meaning. The duty of the courts is to apply the law laid down in statute to the particular facts of the case before them (A Vijayalakshmi Venugopal, 2001). In the 'literal rule', the courts cannot modify the language of the Act if such meaning is clear and unambiguous, effect should be given to the provisions of a statute whatever may be the consequence. In other words, the Court has given a limited interpretation to the words expressed in the statute. Hence, the interpretation of this method is actually a narrow, rigid and strict approach. Accordingly, the 'literal rule' is unsuitable to the interpretation of the provision that guarantees the protection of the fundamental rights of individuals because the interpretation of such provisions should adopt a broad and liberal approach. This was fortified by Jayawickrama that the rules of statutory interpretation do not apply to human rights principles (Philip Alston, 2003). What mentioned by Jayawickrama not only limited to the 'literal rule' but includes others rules of statutory interpretation as well.

Unfortunately, the Paragraph 1 is provided under an ordinary law in which the Court will normally apply the literal rule by giving the wording of Paragraph 1 the ordinary and plain meaning. This is narrow, rigid and strict approach. Therefore, this method of interpretation does not give a room for judicial creativity to flourish. In fact, a plain and ordinary meaning will do more to limit judicial power (James Allan, 2000). Moreover, the use of the literal rule in interpreting Paragraph 1 will also have an impact on the development of Public Interest Litigation (PIL) in Malaysia because under Paragraph 1 of the Schedule to the Courts of Judicature Act 1964, the issue of standing is not specified. Therefore, according to the rules of statutory interpretation by using the literal rule, the Courts cannot simply extend the standing of Public Interest Litigation in Paragraph 1 because it was not the intention of the Parliament. If Parliament intended to allow Public Interest Litigation to be initiated under Paragraph 1, then it must have clearly stated in the Paragraph 1. In conclusion, the rules of statutory interpretation in particular the literal rule is not suitable to the interpretation of the provision that guarantees the protection of the fundamental rights of individuals. Thus, provision of remedies for enforcement of fundamental rights under Paragraph 1 is not suitable to be provided under an ordinary legislation.

\subsection{Judicial Attitude}

Under the ordinary law, the Paragraph 1 of the Schedule to the Courts of Judicature Act 1964 is not noticed by many judges and was not apply since it was introduced in 1964. The situation continued until 1997, when for the first time the Supreme Court in the case of $R$ Ramachandran v The Industrial Court of Malaysia \& Anor [1997] 1 MLJ 145 has applied the powers under Paragraph 1 in providing the relief. For the period of 33 years since the Court of Judicature Act was introduced in 1964 until the decision of Ramachandran in 1997, the provision of remedies for enforcement of fundamental rights under Paragraph 1 was only cited by the Court in seven cases, but the Court missed an opportunity to apply the law concerned. During this period, the English common law has been applied extensively as the prerogative writ was inherited from the British, thus English common law rule has been strictly adhered to. Further, the English common law was widely apply in the era of Pre-Ramachandran is also influenced by our education system because most of the judges and lawyers have legal training in England. Thus, not surprising to find that their approach influenced by the philosophy and approach taken by the English judges and lawyers. In short, the era of the Pre-Ramachandran display the judicial attitudes that influenced by English common law in awarding public law remedies.

In 1997, the case of Ramachandran has change the scene, the Supreme Court for the first time had apply the powers under Paragraph 1 of the Schedule to the Courts of Judicature Act 1964 to extend the powers of judicial review primarily concerned with the powers to mould the relief in accordance with the demands of justice in the circumstances of a particular case. After the case of Ramachandran, our Courts have begun to show a change in attitude as they have begun to apply its powers under Paragraph 1 in public law. Nonetheless, it is surprising because there are some who still fail to understand and appreciate the importance of new developments in public law, either because of ignorance or unwillingness to acknowledge that such authority exists.

Apparently, Malaysian judges have depicted different judicial attitudes in hearing the relief under Paragraph 1 of the Schedule to the Courts of Judicature Act 1964. On one hand, some judges follow the English common law of which they took a rigid, narrow and strict adherence to the technicalities of the English law. On the other hand, some judges took a more liberal, broad and less rigid approach toward interpretation of the provision under Paragraph 1. These different judicial attitudes certainly will cause the conflicting decisions in granting relief under Paragraph 1. Such uncertainty is not good for development of public law. Be it as it may, the tendency of applying values of English common 
law is much higher due to the fact that Malaysian judges had use in-depth the English common law since independence. In addition to that, provision of Paragraph 1 is simply an ordinary law and not a supreme law, therefore the method of interpretation cause it bound by the restrictive rules as in English law. This situation continues to give room to the English common law to evolve rapidly in Malaysian public law.

\section{Prospects under the Constitutional Law}

Challenges faced by the provision of remedies for enforcement of fundamental rights under an ordinary law can be overcome if the provision is enshrined in the Constitution. If the provision of remedies for enforcement of fundamental rights enshrined in the Federal Constitution, the rights will be more secured. This is because duty to preserve and defend the constitution rests on the shoulders of the Court. The court is clearly envisaged as the guardian and interpreter of the Constitution (Holden Furber, 1949). The Courts were made equal in origin and equal in title to the other two branches of the government and were charged with the inescapable duty of guarding the fundamental rights and preventing infringements of the rule of law by any authority within the State (N.A. Palkhivala, 1988). Hence, when a provision of remedies for enforcement of fundamental rights is guaranteed, indirectly the fundamental rights under the Constitution will also be protected because if the fundamental rights are violated, those rights can be enforced by the constitutional remedies.

In Malaysia, only the Constitution is supreme (Tunku Sofian Jewa et al, 2007). As the Constitution is the supreme law, the fundamental law of the land, it is paramount to others law. Therefore, if there be a law passed which is inconsistent with the Constitution shall, to the extent of their inconsistency or contravention with the constitution, be void. Further, the doctrine of supremacy of the Constitution is also reflected in the third pillars of the nation (known as "Rukun Negara") in Malaysia. The supremacy of the Constitution means that Constitution is supreme over the Parliament (Jutta Limbach, 2001). With the doctrine of supremacy of the Constitution, the Court as the guardian of the Constitution were actually supplied with an effective weapons to defend the Constitution from infringed by any ordinary law that attempts to limit or curtail the rights under the Constitution. In addition, the Constitution as a higher law of the land, it is superior. Thus, it cannot be amended through a normal procedure. Hence, if the provision of remedies for enforcement of fundamental rights enshrined under the Federal Constitution it will be protected and safeguarded by the doctrine of supremacy of the Constitution.

The provisions of the Federal Constitution are also guaranteed by the doctrine of basic structure. Under this doctrine, all the provisions of the Constitution can be amended with the condition that the amendment retains the same basic structure, and the basic structure is not destroyed by any form of amendments. This doctrine was first stated by the Supreme Court of India in the case of Bharathi Kesavananda Sripadagalvaru \& Ors v State of Kerala \& Anor AIR 1973 SC 1461. Around 80's, this doctrine has been raised in Malaysia but the Malaysian Courts, including the Supreme Court had rejected the doctrine. Over recent years, the judicial attitude has changed in which the doctrine of basic structure has been recognised and accepted by the Malaysian courts including the Federal Court. It is to be noted that in India, the provision of remedies for enforcement of fundamental rights under Article 32 and 226 of the Constitution has been said to form part of the basic structure of the Indian constitution. Therefore, if the remedies for enforcement of fundamental rights under Paragraph 1 is enshrined under the Federal Constitutions, it is also form part of the basic structure of the Malaysian Federal Constitution. Even if the Parliament has two-thirds majority to amend the Federal Constitution, but if the amendment would destroy the basic structure of the Constitution, the amendment can be challenged in Court. This is another safeguard that can be provided by the doctrine of basic structure to the provision of remedies for enforcement of fundamental rights.

In terms of interpretation, the method of interpretation of the Constitution is different from the interpretation of an ordinary law. According to Samuel Freeman, there are two approaches in the interpretation of the Constitution. The first, "interpretivism", involves deciding constitutional issues by enforcing norms explicitly stated or clearly implied in the written constitution. The second, "non-interpretivism", goes beyond these references to enforce norms that cannot be discovered within the "four corners of the document" (Samuel Freeman, 1992). In other words, the approaches that apply to interpret the Constitution can be the literal interpretation or a liberal interpretation. No doubt, at one time it was thought that the same rules governing the interpretation of an ordinary law is also applied for the interpretation of the written Constitution. However, the shift toward a liberal and broad interpretation in construing a written Constitution has begun in many other jurisdictions. Following many other jurisdictions, Malaysian courts have demonstrated a noticeable trend from the traditional narrow approach towards a broad and liberal approach towards Constitution's interpretation (Yogeswaran Subramaniam, 2011).

It is pertinent to notes that a broad and liberal approach is more suitable to be applied in the interpretation of a 
written Constitution. This is because a broad and liberal approach will give the courts more rooms for applying judicial creativity and enjoy large remedial powers. So, if the provision of remedies for enforcement of fundamental rights under Paragraph 1 is enshrined under the Constitution, the courts have more rooms for judicial creativity in devise a remedy suitable to the circumstances of a specific case. Further, the courts can seek to tailor and mould the reliefs in accordance with the demands of justice in the circumstances of a specific case and may even order the administration to take affirmative action in a given situation. Therefore, with the judicial creativity the judges are as if holding a scalpel instead of an axe: a tool that may fashion a suitable remedy to fit the factual matrix of a particular case. Everything on this can only be done with the application of a broad and liberal approach in interpreting the Constitution. Accordingly, the text of the Constitution is typically more obscure and uncertain than the text in a statute. The intention is to create more rooms for judicial creativity in solving the doubt.

Further, the judicial creativity is also important for the development of public interest litigation (PIL). The best example for description is the Constitution of India, whereby the issue of standing is not stated in the constitutional remedies under Article 226 of the Indian Constitution (in pari materia with paragraph 1 of the Schedule to the Courts of Judicature Act 1964). However, Justice P.N. Bhagwati in the case S.P. Gupta v Union of India AIR 1982 SC 149 has adopted a liberal approach to relax the traditional rule of locus standi. The court had interpreted Article 226 of the Indian Constitution in a liberal and creative way to allow standing to any pro bono publico. Now the rule of locus standi has been made broad based and people-oriented to allow access to justice through public interest litigation (P. L. Mehta at al, 1999). This creative and liberal approach can be done by the High Court of India as Article 226 is enshrined under the Indian Constitution. Moreover, the Constitution gives certain rights to an individual, thus the language in the Constitution should receive a broad and liberal construction. This is to ensure that the people gain the benefit from the Constitution that intended to give to them. In the Constitution, there is number of non-enumerated rights emerging from the rights enumerated in the supreme law. But that will only happen if courts interpret the Constitution as it should be interpreted, that is to say, in a broad and liberal fashion adopting a prismatic approach. If the approach of "tabulated legalism" is adopted then the Court will not find anything in the document (Gopal Sri Ram, 2007).

If the provision of remedies for enforcement of the fundamental rights enshrined in the Federal Constitution, it also able to change the judicial attitude of some judges that are bound by the English common law as the Constitution is the supreme law and paramount to other laws. Therefore, the law either in existing or future, must be in conformity with the Constitution (Muhammad Munir, 1975). Finally, the enhanced legal status of the Paragraph 1 will certainly affect the judicial attitude because the Constitutional status of Paragraph 1 will send a clear message to the courts that the restrictive, narrow and archaic values of the English common law which at times characterized their approach to the Paragraph 1 under ordinary law should be departed by our judges. This proven workable in Canada when the enhanced legal status of the Canadian Charter of Rights and Freedoms had a great impact on the judicial behaviour, both in their words and in their deeds, Canadian judges have begun to carve out a bold new constitutional jurisprudence (F.L. Morton, 1987).

\section{Conclusion}

Rights without a remedy are meaningless. Recognising the importance of both rights and remedies, the Reid Constitutional Commission had proposed the provision of fundamental rights and remedies for enforcement of those rights to be assured by the Constitution. However, the Working Party, whose duty to revise the proposal of the Reid Commission Report had just accepted the underlying rights in Part II of the Federal Constitution and remove the proposed constitutional remedies from the draft Constitution on the basis that it is impracticable to provide the remedies within the bounds of the Constitution but the sufficient remedies can best be provided by the ordinary law. Ever since the debut of the provision of remedies for enforcement of fundamental rights under Paragraph 1 up until to date, it has established that the alleged provision of which is provided under an ordinary statute has caused troubles and has largely affected the development of the Malaysian public law. This clearly demonstrated that the testimonial of the Working Party to remove the constitutional remedies from the draft constitution as proposed by the Reid Commission was incorrect. To rectify the situation, the best thing to suffice is to incorporate the remedies into the Constitution which will run to the broadening and strengthening of the scope of judicial review. Thus, the current Malaysian framework in the Paragraph 1 of the Schedule to the Courts of Judicature Act 1964 urgently needs to be elevated into the Constitution. 


\section{References}

A Vijayalakshimi Venugopal. (2001). Introduction to Law in Malaysia, Malaysia: Sweet \& Maxwell Asia.

Ahmad Masum. (2012). The Doctrine Of Ministerial Responsibility In Malaysia: Theory And Practice In A New Regime Of Parliamentary Accountability. Malayan Law Journal, 4 clv.

Choo Chin Thye. (20012). The Role Of Article 8 Of The Federal Constitution In The Judicial Review Of Public Law In Malaysia. Malayan Law Journal, 3 civ.

F. L. Morton. (1987). The Political Impact of the Canadian Charter of Rights and Freedoms. Canadian Journal of Political Science, 20 (1), 31.

Gopal Sri Ram. (2007). The Workman And The Constitution. Malayan Law Journal Articles, 1 clxxii.

Holden Furber. (1949). Constitution-Making in India. Far Eastern Survey, 18 (8), 86.

James Allan. (2000). Constitutional interpretation V. Statutory interpretation: Understanding the Attractions of 'Original Intent. Legal Theory. 6 (1), 109.

Jutta Limbach. (2001). The Concept of the Supremacy of the Constitution. The Modern Law Review, 64 (1), 1.

Muhammad Munir. (1975). Constitution of the Islamic Republic of Pakistan: A Commentary on the Constitution of Pakistan 1973, Lahore: Law Publishing Company.

N.A. Palkhivala. (1975). Our Constitution : Defaced And Defiled, India: Macmillan.

Oliver Wijetillake. (1982). Public Policy Functions of Supreme Courts And The Independence of The Judiciary. Current Law Journal (Reprint), xciv.

Philip Alston. (2003). Book Reviews - The Judicial Application of Human Rights Law: National, Regional and International Jurisprudence. European Journal of International Law, 14 (3), 615.

P. L. Mehta et al. (1999). Human Rights Under The Indian Constitution: The Philosophy And Judicial Gerrymandering. India: Deep \& Deep Publication.

V Anantaraman. (2006). The Extended Powers of Judicial Review in Malaysian Industrial Relations: A Review. Malayan Law Journal, 4 cxiv.

Samuel Freeman. (1992). Original Meaning, Democratic Interpretation, and the Constitution. Philosophy \& Public Affairs, 21 (1), 3.

Tunku Sofian Jewa et al (editors). (2007). Tun Mohamed Suffian's An Introduction to the Constitution of Malaysia, Third Edition, Malaysia: Pacifica Publications.

Yogeswaran Subramaniam. (2012). The 'UNDRIP' And The Malaysian Constitution: Is Special Recognition And Protection Of The Orang Asli Customary Lands Permissible? Malayan Law Journal Articles, 2 cxxvi. 